\title{
PENILAIAN KONDISI VISUAL DAN PREDIKSI USIA SISA JEMBATAN SILITI DENGAN METODE BRIDGE MANAGEMENT SYSTEM
}

\author{
ASSESSMENT OF VISUAL CONDITIONS AND PREDICTION OF THE REMAINING LIFE OF THE \\ SILITI BRIDGE USING THE BRIDGE MANAGEMENT SYSTEM METHOD
}

\author{
Adi Setiawan $^{* 1}$, Sumargo ${ }^{2}$ \\ ${ }^{1}$ Mahasiswa, Magister Teknik Rekayasa Infrastruktur, Jurusan Teknik Sipil, Politeknik Negeri Bandung \\ ${ }^{2}$ Dosen, Jurusan Teknik Sipil, Universitas Jenderal Achmad Yani, Bandung \\ Korespondensi: adi.setiawan.mtri19@polban.ac.id
}

\begin{abstract}
ABSTRAK
Salah satu upaya pemeliharaan jembatan adalah dengan melakukan penilaian awal dengan penilaian visual. Hal ini dilakukan untuk menjaga usia jembatan dan mencegah kerusakan pada struktur berkelanjutan yang mungkin terjadi di masa depan. Pertumbuhan jumlah kendaraan setiap waktu akan menghasilkan risiko penurunan kapasitas jembatan dan usianya. Pasca konstruksi dan pemeliharaan merupakan waktu penting dalam infrastruktur. Hal ini sering dikesampingkan, sehingga menyebabkan fungsi dan kinerja jembatan menurun dan akhirnya menyebabkan kerusakan. Jembatan Siliti adalah jembatan beton yang terletak di Kec. Bungku Utara, Kab. Morowali, Sulawesi Tengah. Jembatan ini mendapat perhatian khusus karena kondisinya yang cukup parah. Tujuan inspeksi pada Jembatan Siliti untuk mengetahui kondisinya secara visual dan menentukan perkiraan usia jembatan yang tersisa yang akan menjadi modal untuk pemeriksaan lebih lanjut. Bridge Management System (BMS) adalah sistem penilaian untuk menilai kondisi yang ada dari setiap elemen jembatan. BMS mencakup manajemen yang mencakup inspeksi, perencanaan hingga pemeliharaan. Nilai kondisi dari jembatan diperlukan untuk menghitung usia sisanya. Berdasarkan evaluasi yang dilakukan pada tahun 2017, nilai Jembatan Siliti menggunakan standar BMS adalah 3 (Rusak). Usia yang tersisa dari Jembatan Siliti adalah 8 tahun.
\end{abstract}

Kata Kunci: Asesmen Jembatan, BMS, Jembatan, Siliti, Usia Sisa

\section{ABSTRACT}

One of the efforts in bridge maintenance is by conducting a preliminary assessment with a visual assessment. Growth in the number of vehicles each time will result in a risk of decreasing the capacity of the bridge and its age. Post-construction and maintenance is also a major requirement in infrastructure. This is often ruled out causing the bridge's function and performance to decline and ultimately cause damage. Siliti Bridge is a concrete bridge located in North Bungku Morowali, Sulawesi Tengah. This bridge gets special attention due to quite severe conditions. 
The purpose of the inspection on the Siliti Bridge is to get its condition visually and determine the estimated age of the remaining bridge which will be capital for further inspection. Bridge Management System (BMS) is a system of assesment to know the existing condition of each element of the bridge. The condition value of the bridge is needed to calculate its remaining life. Based on evaluations conducted in 2017, the value of the Siliti Bridge using the BMS standard is 3 (Damaged). The remaining age of the Siliti Bridge is 8 years.

\section{Keywords: BMS, Bridge, Bridge Asesment, Remaining Life, Siliti}

\section{PENDAHULUAN}

Menurut Sudradjat, Djakfar dan Zaika, (2015) jembatan merupakan satu dari sekian infrastruktur yang berperan penting dalam sistem jalan. Jembatan menjadi penghubung daerah satu dengan daerah lain sehingga dapat melewati halangan dengan mudah. Ketika jembatan mengalami kerusakan maka akan menghambat dan menahan lalu lintas kendaraan. Jembatan beton bertulang sangat rentan terhadap kerusakan awal yang timbul dan dapat mengakibatkan kerusakan jangka panjang jika tidak segera dirawat atau diperbaiki. Kerusakan awal terjadi pada masa pemeliharaan, hal ini mungkin terjadi dikarenakan kesalahaan dalam perencanaan atau pada pelaksanaannya. Kerusakan jangka panjang terjadi setelah masa pemeliharaan, kerusakan ini terjadi dikarenakan perubahan beban kendaraan yang meningkat dan pengaruh dari daerah sekitar maupun keadaan tidak terduga seperti gempa, angin, kebakaran dan korosi (Indianto, 2016). Jembatan Siliti merupakan jembatan yang terletak di Desa Siliti, Kec. Bungku Utara, Kab. Morowali Utara, Provinsi Sulawesi Tengah. Jembatan ini menghubungkan Desa Rata dan Baturube, dibangun pada tahun 1999 dengan bentang 14,8 meter dan lebar 6,3 meter.

Jembatan yang sudah dibangun sejak tahun 1999 ini secara jelas terlihat kerusakan pada strukturnya dengan banyak kerusakan cukup parah pada beberapa bagiannya. Maka, kondisi dari jembatan perlu untuk dianalisis kembali keadaan eksistingnya sehingga dapat diketahui elemen yang kritis dan perlu perbaikan dengan segera serta menentukan nilai usia sisa dari Jembatan Siliti.

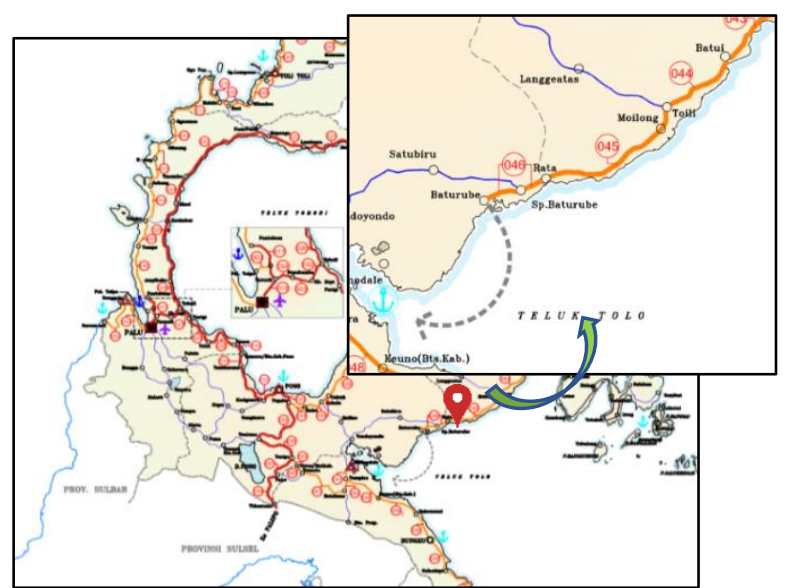

Gambar 1. Peta Ruas Jalan Provinsi Sulawesi Tengah

Sumber: Dirjen Pekerjaan Umum Provinsi Sulawesi Tengah (2014)

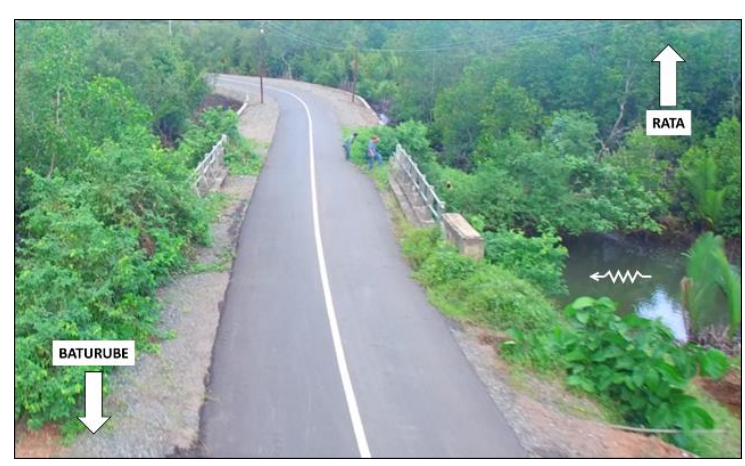

Gambar 2. Tampak Atas Jembatan Siliti Sumber: Hasil Pemeriksaan (2017)

Usia Jembatan Siliti yang cukup tua membuat struktur jembatan perlu dievaluasi. Penilaian dilakukan dengan tujuan pencegahan terhadap kerusakan lanjut dan jangka panjang pada jembatan. Penilaian memberikan tahap awal dalam penentuan perawatan yang akan dilakukan. Beberapa metode yang sering digunakan dalam penilaian jembatan adalah NYSDOT, metode FCM, metode PHA dan BMS. Menurut Hariman, H dan Triwiyono (2007), metode ini digunakan untuk mendapatkan kondisi eksisting jembatan dengan metode survei visual menggunakan alat elektronik seperti teropong, kamera, dan berbagai alat lainnya, sehingga didapatkan detil kerusakan secara material ataupun 
struktural pada jembatan. Penilaian yang digunakan dalam kajian ini berfokus pada metode BMS. Tujuan penilaian kondisi jembatan dilakukan dalam penentuan tindakan koreksi atau pemeliharaan yang tepat.

\section{TINJAUAN PUSTAKA}

\section{Bridge Management System}

Menurut Direktorat Jenderal Bina Marga Departemen Pekerjaan Umum (1993) Bridge Management System (BMS) merupakan sistem manajemen pada jembatan yang ditujukan untuk pembuatan agenda, pelaksanaan, dan monitoring pada jembatan. Elemen-elemen pada jembatan akan dibagi menjadi beberapa tingkatan pada tahap pemeriksaan jembatan. Berdasarkan BMS, tingkatan tersebut dibagi menjadi 5 tingkat, dimana masingmasing tingkatan memiliki kode elemen. Pemeriksaan dilakukan secara akurat pada jembatan, termasuk menilai kondisi rinci dari setiap elemenelemen jembatan yang kerusakannya terlihat secara visual.

Rasidi et al., (2017) menjelaskan bawah pada penilaian kondisi dengan metode BMS nilai dari setiap kerusakan akan dikategorikan dengan 5 tingkat: tingkat paling tinggi yaitu tingkat 1 dan tingkat terendah adalah tingkat 5 . tingkat dengan nilai rendah mengartikan kondisi yang lebih bagus dan begitupun sebaliknya.

Tabel 1. Nilai Kondisi Jembatan

\begin{tabular}{|c|c|c|}
\hline Nilai & Kriteria & $\begin{array}{l}\text { Nilai } \\
\text { Kondisi }\end{array}$ \\
\hline \multirow[t]{2}{*}{ Struktur (S) } & Berbahaya & 1 \\
\hline & Tidak Berbahaya & 0 \\
\hline \multirow{3}{*}{$\begin{array}{l}\text { Kerusakan } \\
\text { (R) } \\
\text { Kuantitas (K) }\end{array}$} & Parah & 1 \\
\hline & Tidak Parah & 0 \\
\hline & $\begin{array}{l}\text { Lebih dari } 50 \% \\
\text { Kurang dari } 50 \%\end{array}$ & $\begin{array}{l}1 \\
0\end{array}$ \\
\hline Fungsi (F) & $\begin{array}{l}\text { Elemen tidak berfungsi } \\
\text { Elemen } \\
\text { berfungsi }\end{array}$ & 1 \\
\hline \multirow[t]{2}{*}{ Pengaruh (P) } & $\begin{array}{l}\text { Mempengaruhi elemen } \\
\text { lain }\end{array}$ & 1 \\
\hline & $\begin{array}{l}\text { Tidak mempengaruhi } \\
\text { elemen lain }\end{array}$ & 0 \\
\hline $\begin{array}{l}\text { Nilai Kondis } \\
\text { (NK) }\end{array}$ & $\mathrm{NK}=(\mathrm{S}+\mathrm{R}+\mathrm{K}+\mathrm{F}+\mathrm{P})$ & $\mathrm{s} / \mathrm{d}$ \\
\hline
\end{tabular}

Sumber: Dirjen Bina Marga dan Departemen Pekerjaan Umum (1993)

Nilai kondisi dari tiap elemen bangunan akan dijumlahkan dan akan didapatkan nilai kondisi secara keseluruhan antara 0 sampai dengan 5. Nilai tersebut dapat dijadikan patokan untuk tahap penyelidikan lebih lanjut.

Selanjutnya, nilai kondisi dari pemeriksaan setiap elemen-elemen jembatan dideskripsikan sesuai dengan Tabel 2.

Tabel 2. Deskripsi Nilai Kondisi Jembatan

\begin{tabular}{cl}
$\begin{array}{c}\text { Nilai } \\
\text { Kondisi }\end{array}$ & \multicolumn{1}{c}{ Deskripsi } \\
\hline 0 & $\begin{array}{l}\text { Baik Sekali/jembatan dalam kondisi } \\
\text { baru }\end{array}$ \\
1 & Baik/tidak terjadi kerusakan \\
2 & Rusak Ringan \\
3 & Rusak \\
4 & Rusak Kritis \\
5 & Runtuh/tidak berfungsi
\end{tabular}

Sumber: Dirjen Bina Marga dan Departemen Pekerjaan Umum (1993)

Berdasarkan BMS Panduan Pemeriksaan Jembatan 1993, Nilai Kondisi dengan jumlah 0 berarti jembatan dalam keadaan baru dan tidak memiliki kerusakan. Elemen dari setiap jembatan kondisinya masih sangat baik.

Nilai Kondisi dengan jumlah 1 berarti jembatan memilki kerusakan yang sangat sedikit, dimana kerusakan tersebut dapat diperbaiki dengan pemeliharaan rutin, dan tidak berpengaruh terhadap keamanan maupun fungsi dari jembatan tersebut. Contohnya adalah sedikit scour pada pilar, karat pada permukaan, ataupun papan kayu yang longgar.

Nilai Kondisi dengan jumlah 2 mengartikan bahwa kerusakan pada jembatan memerlukan pemeliharaan pada masa mendatang. Contohnya pembusukan pada struktur kayu, penumpukan sampah pada sekitar, dan lain sebagainya.

Nilai Kondisi dengan jumlah 3 jembatan dikatakan rusak, dimana kerusakan tersebut diperlukan perhatian dengan kemungkinan akan menjadi serius pada waktu 12 bulan kemudian. Contohnya struktur betin yang retak, timbul gundukan aspal pada lantai jembatan, dan lainnya.

Nilai Kondisi 4 berarti jembatan berada dalam kondisi kritis dengan kerusakan serius dan perlu perhatian secepatnya. Contohnya adalah kegagalan rangka, pondasi yang terkikis, dan lain sebagainya. 
Elemen jembatan yang runtuh dan tidak berfungsi lagi nilai kondisinya pasti berada di angka 5. Kondisi ini memerlukan perbaikan besar atau bahkan penggantian jembatan seluruhnya.

\section{Penyaringan Kondisi Jembatan}

Kegiatan penyaringan kondisi jembatan merupakan salah satu kegiatan dalam manajemen jembatan. Menurut Hariman, H dan Triwiyono (2007), penyaringan kondisi jembatan merupakan penyaringan terhadap data-data dari nilai kondisi jembatan yang mengalami penurunan kualitas kekuatan, menurunnya kapasitas lalu lintas, dan kondisi yang buruk, sehingga memerlukan penanganan. Menurut BMS BMS Panduan Pemeriksaan Jembatan 1993, kriteria penyaringan terdapat pada Tabel 3.

Tabel 3. Penyaringan Kondisi Jembatan

\begin{tabular}{llrl}
\hline Nilai & Kategori & Penanganan Indikatif \\
\hline $0-2$ & Baik s/d & Pemeliharaan Rutin / \\
& Rusak Ringan & Berkala \\
3 & Rusak Berat & Rehabilitasi \\
4,5 & Kritis atau & Penggantian \\
& Runtuh & \\
\hline
\end{tabular}

Sumber: Dirjen Bina Marga dan Departemen Pekerjaan Umum (1993)

\section{Usia Sisa Jembatan}

Usia sisa jembatan didapatkan dari nilai kondisi eksisting jembatan, berbagai factor mempengaruhi nilai dari kondisi jembatan seperti faktor lingkungan dan juga tingkat kerusakan yang terjadi pada setiap elemennya. Analisis perhitungan usia sisa jembatan menggunakan acuan Panduan Penanganan Preservasi Jembatan.

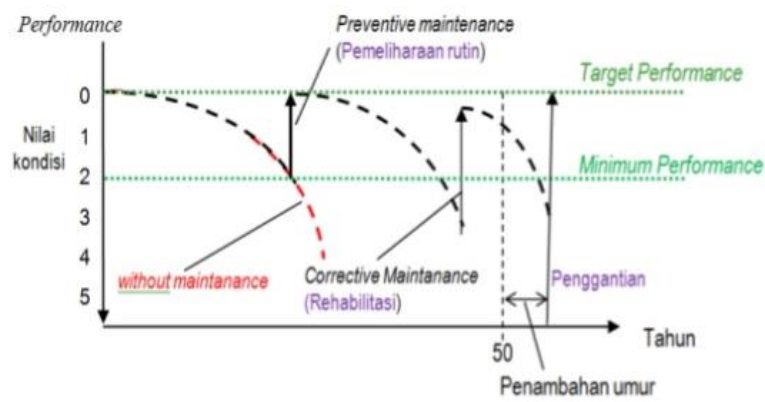

Gambar 3. Grafik Usia Sisa Jembatan

Sumber: Panduan Penanganan Preservasi Jembatan (2010)

Berdasarkan grafik, perhitungan usia sisa jembatan dapat menggunakan persamaan berikut:

$$
N K=5-\left\{\frac{\left(100-\frac{Y}{N \%}\right)}{a}\right\}\left(\frac{1}{b}\right)
$$

$$
\begin{array}{ll}
\text { NK } & \text { : Nilai Kondisi } \\
\mathrm{Y} & : \text { Usia Jembatan } \\
\mathrm{N} & : \text { Usia Rencana } \\
\mathrm{a} & : \text { Koefisien }(4,66) \\
\mathrm{b} & : \text { Koefisien }(1,9051)
\end{array}
$$

\section{METODOLOGI PENELITIAN}

Metodologi pada penelitian ini mengggunakan metode kuantitatif. Data nilai kondisi jembatan didapatkan dengan pemeriksaan secara visual di lapangan. Di dalam manajemen informasi BMS dicantumkan kegiatan manajemen jembatan berupa pemeriksaan, perencanaan, pemeliharaan, dan implementasinya. BMS dapat mengatur kegiatan secara teratur dan rutin hingga kondisi dari jembatan terlihat. Beberapa tindakan lanjutan mungkin diperlukan sebagai konfirmasi bahwa jembatan masih aman untuk digunakan.

\section{HASIL DAN PEMBAHASAN}

\section{Data Teknis Jembatan}

Jembatan Siliti berada di Kecamatan Bungku Utara, Kabupaten Morowali, Sulawesi Tengah.

$\begin{array}{ll}\text { Nama Jembatan } & : \text { Jembatan Siliti } \\ \text { Masa Layan } & : \text { 50 Tahun } \\ \text { Tahun Bangun } & : \text { 1999 } \\ \text { Panjang Jembatan } & : 14,8 \text { Meter } \\ \text { Lebar Jembatan } & : 6,3 \text { Meter } \\ \text { Koordinat Lokasi } & : 1^{\circ} 43 \text { '34.9"LU-121 } 488^{\prime} 50.3^{\prime \prime B T} \\ \text { Tipe Jembatan } & : \text { Beton Bertulang } \\ \text { Jenis Bentang } & : \text { Bentang Pendek } \\ \text { Jumlah Bentang } & : \text { 1 Bentang } \\ \text { Jenis Lintasan } & : \text { Sungai }\end{array}$

Jembatan Siliti menghubungkan akses jalan dari Desa Baturube ke Desa Rata karena terdapat sungai. Jembatan Siliti tergolong jembatan bentang pendek dengan tipe jembatan beton bertulang.

\section{Hasil Pemeriksaan}

Proses penilaian kondisi jembatan merupakan langkah awal untuk mengevaluasi keadaan jembatan sebelum pemeriksaan tahap lanjutnya. Nilai penilaian akan dijadikan patokan prioritas bagian yang akan diperbaiki terlebih dahulu. Nilai kondisi keseluruhan jembatan dapat dilihat pada 
Tabel 11.

Hasil yang diperoleh setelah melakukan inspeksi:

1. Lapisan atas masih cukup baik namun saluran airnya hilang karena tertutup kerikil dan tanaman. Tanaman liar merambat hingga ke permukaan jalan. Saran penanganan adalah dengan pembersihan lantai jembatan dari tanaman liar

Tabel 4. Nilai Kondisi Lapisan Atas

\begin{tabular}{ccccccccc}
\hline No. & $\begin{array}{c}\text { Tipe } \\
\text { Struktur }\end{array}$ & S & R & K & F & P & NK & $\begin{array}{c}\text { Tingkat } \\
\text { Kerusakan }\end{array}$ \\
\hline 1. & $\begin{array}{c}\text { Lapisan } \\
\text { Atas }\end{array}$ & 1 & 0 & 1 & 0 & 0 & 2 & $\begin{array}{c}\text { Rusak } \\
\text { Ringan }\end{array}$ \\
\hline \multicolumn{1}{c}{ Nilai Kondisi Rata -rata } & & 2 & $\begin{array}{c}\text { Rusak } \\
\text { Ringan }\end{array}$ \\
\hline
\end{tabular}

Sumber: Hasil Pemeriksaan (2017)

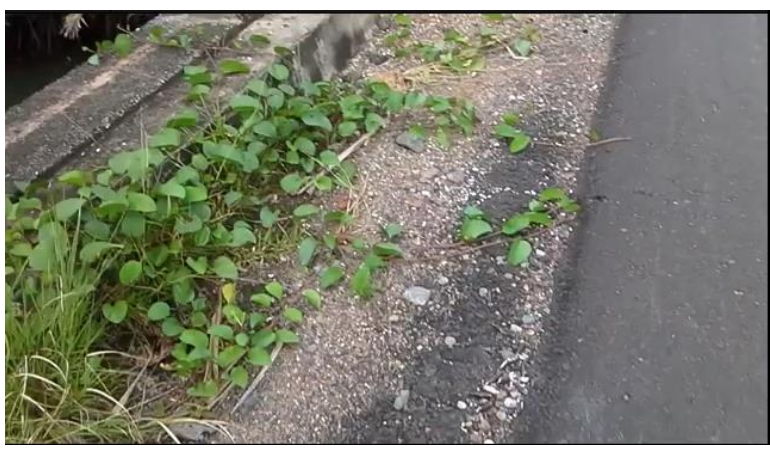

Gambar 4. Saluran Air Tertutup

Sumber: Hasil Pemeriksaan (2017)

2. Beberapa bagian railing hilang dan tidak cukup baik, Penyangga railing memiliki ukuran dan ketinggian yang berbeda.

Tabel 5. Nilai Kondisi Railing

\begin{tabular}{ccccccccccc}
\hline No & $\begin{array}{c}\text { Tipe } \\
\text { Struktu } \\
\text { r }\end{array}$ & S & R & K & F & P & $\begin{array}{c}\text { N } \\
\text { K }\end{array}$ & $\begin{array}{c}\text { Tingkat } \\
\text { Kerusaka } \\
\text { n }\end{array}$ \\
\hline 1. & Railing & 1 & 0 & 0 & 1 & 0 & 2 & $\begin{array}{c}\text { Rusak } \\
\text { Ringan }\end{array}$ \\
\hline \multicolumn{7}{c}{ Nilai Kondisi Rata -rata } & & & 2 & $\begin{array}{c}\text { Rusak } \\
\text { Ringan }\end{array}$ \\
\hline
\end{tabular}

Sumber: Hasil Pemeriksaan (2017)

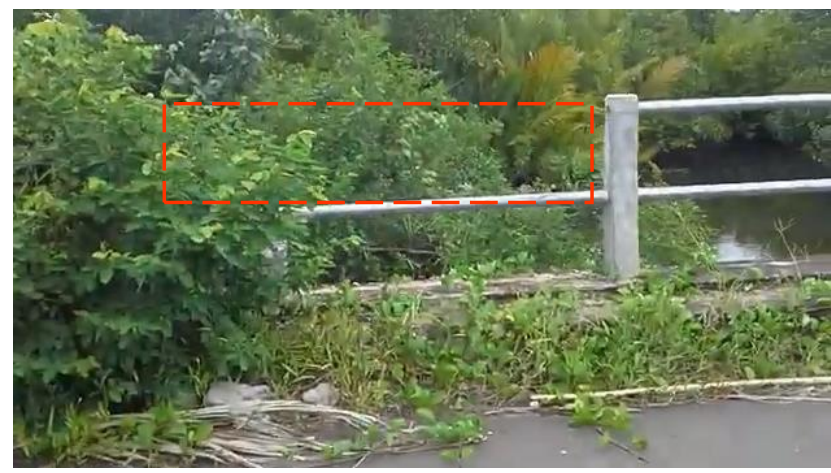

Gambar 5. Railing yang hilang

Sumber: Hasil Pemeriksaan (2017)

3. Dimensi dari pelat lantai untuk pejalan kaki tidak sama tinggi/ tidak rata. Saran penanganan berupa grouting untuk membentuk kembali pelat yang sama rata

Tabel 6. Nilai Kondisi Pelat lantai

\begin{tabular}{ccccccccc}
\hline No. & $\begin{array}{c}\text { Tipe } \\
\text { Struktur }\end{array}$ & S & R & K & F & P & NK & $\begin{array}{c}\text { Tingkat } \\
\text { Kerusakan }\end{array}$ \\
\hline 1. & $\begin{array}{c}\text { Pelat } \\
\text { Lantai }\end{array}$ & 0 & 0 & 0 & 1 & 0 & 1 & Baik \\
\hline
\end{tabular}

Nilai Kondisi Rata -rata $\quad 1 \quad$ Baik

Sumber: Hasil Pemeriksaan (2017)

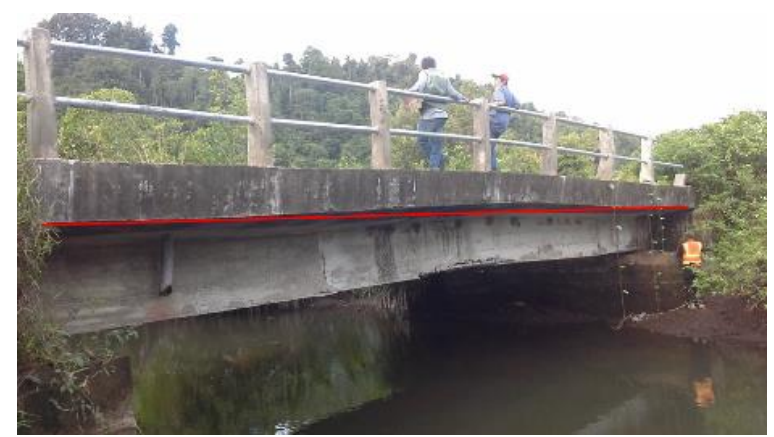

Gambar 6. Pelat lantai tidak rata

Sumber: Hasil Pemeriksaan (2017)

4. Bagian selimut beton pada gelagar sudah lapuk dan terkelupas, bahkan tulangan terlihat dengan jelas dan sudah berkarat. Retakan terlihat jelas pada gelagar jembatan dengan posisi yang tipikal. Hal ini beresiko terjadi keruntuhan jembatan secara keseluruhan. Saran penanganan berupa perbaikan keseluruhan pada gelagar. tulangan perlu diganti dan perlu dilakukannya grouting untuk membuat gelagar kembali utuh. Untuk menghindari kerusakan lagi, grouting menggunakan beton tak susut dan lakukan pemasangan bearing. 
Penilaian Kondisi Visual..., Adi Setiawan ${ }^{(1)}$, Sumargo $^{(2)}$

Tabel 7. Nilai Kondisi Gelagar

\begin{tabular}{|c|c|c|c|c|c|c|c|c|}
\hline No. & $\begin{array}{c}\text { Tipe } \\
\text { Struktur }\end{array}$ & $\mathrm{S}$ & $\mathrm{R}$ & K & $\mathrm{F}$ & $\mathrm{P}$ & NK & $\begin{array}{c}\text { Tingkat } \\
\text { Kerusakan }\end{array}$ \\
\hline 1. & Gelagar & 1 & 1 & 0 & 1 & 1 & 4 & $\begin{array}{c}\text { Rusak } \\
\text { Kritis }\end{array}$ \\
\hline & Nilai Ko & & & & & & 4 & $\begin{array}{l}\text { Rusak } \\
\text { Kritis }\end{array}$ \\
\hline
\end{tabular}

Sumber: Hasil Pemeriksaan (2017)

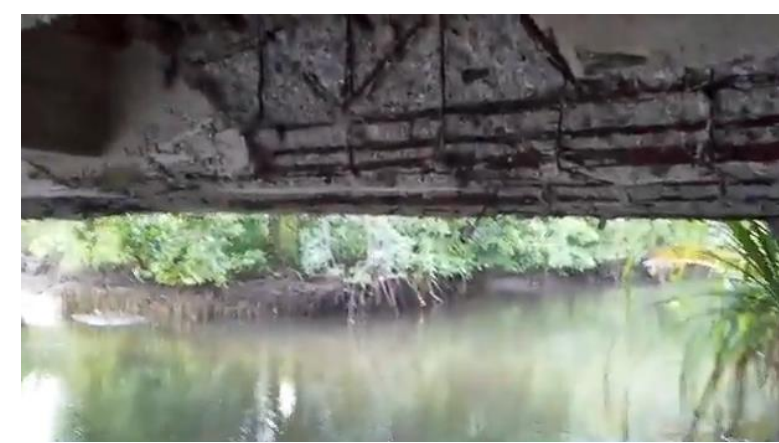

Gambar 7. Beton keropos hingga tulangan terlihat dan terkorosi

Sumber: Hasil Pemeriksaan (2017)

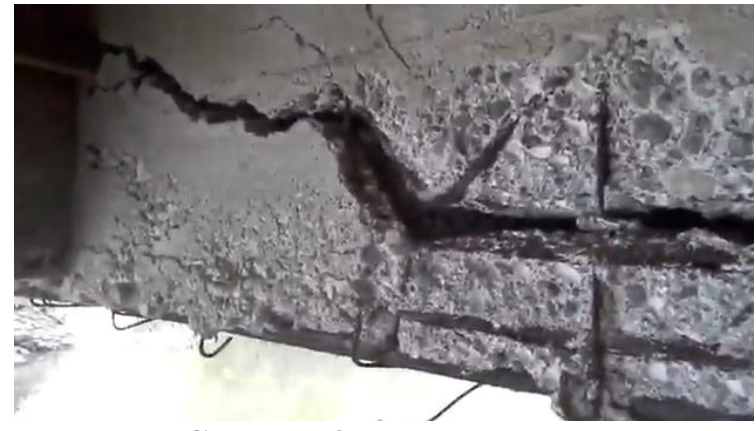

Gambar 8. Gelagar Retak

Sumber: Hasil Pemeriksaan (2017)

5. Bearing Pad bahkan sudah tidak lagi terlihat, sehingga gelagar langsung menumpu pada abutment. Saran penanganan adalah pemasangan bearing secepatnya.

Tabel 8. Nilai Kondisi Bearing Pad

\begin{tabular}{ccccccccc}
\hline No. & $\begin{array}{c}\text { Tipe } \\
\text { Struktur }\end{array}$ & S & R & K & F & P & NK & $\begin{array}{c}\text { Tingkat } \\
\text { Kerusakan }\end{array}$ \\
\hline 1. & $\begin{array}{c}\text { Bearing } \\
\text { Pad }\end{array}$ & 0 & 0 & 0 & 1 & 1 & 2 & $\begin{array}{c}\text { Rusak } \\
\text { Ringan }\end{array}$ \\
\hline \multicolumn{1}{c}{ Nilai Kondisi Rata -rata } & & 2 & $\begin{array}{c}\text { Rusak } \\
\text { Ringan }\end{array}$ \\
\hline
\end{tabular}

Sumber: Hasil Pemeriksaan (2017)

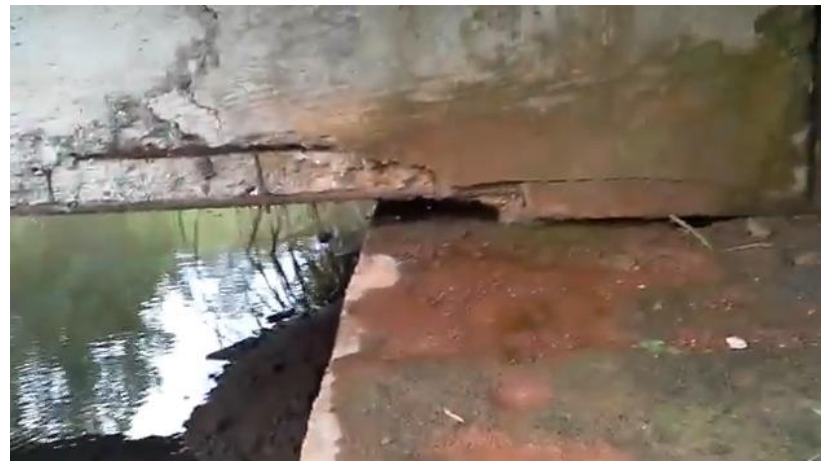

Gambar 9. Bearing pad sudah tidak terlihat Sumber: Hasil Pemeriksaan (2017)

6. Dinding abutment gerompal dan retak besar karena korosi tulangan mendesak beton dan pecah. Tulangan vertikal juga sudah terbuka.

Tabel 9. Nilai Kondisi Abutment

\begin{tabular}{ccccccccc}
\hline No. & $\begin{array}{c}\text { Tipe } \\
\text { Struktur }\end{array}$ & S & R & K & F & P & NK & $\begin{array}{c}\text { Tingkat } \\
\text { Kerusakan }\end{array}$ \\
\hline 1. & Abutment & 1 & 0 & 1 & 1 & 0 & 3 & Rusak \\
\hline \multicolumn{1}{c}{ Nilai Kondisi Rata - rata } & & 3 & Rusak \\
\hline Sumber: Hasil Pemeriksaan (2017) & &
\end{tabular}

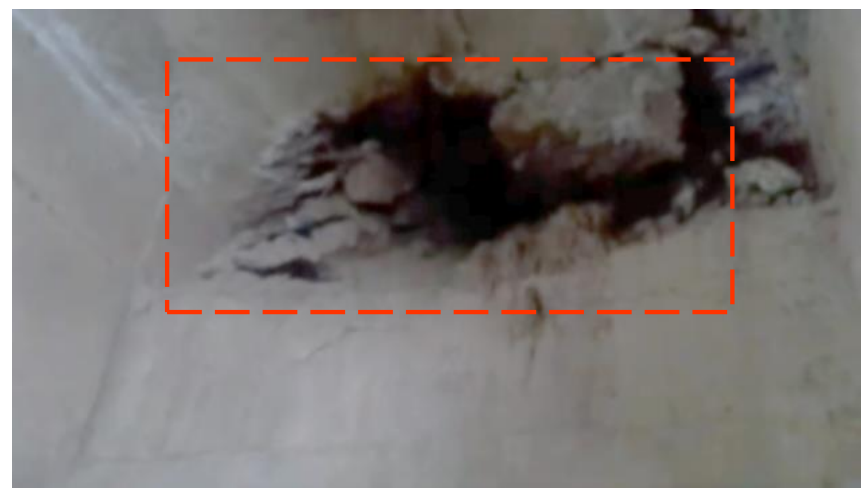

Gambar 10. Abutment yang gerompal Sumber: Hasil Pemeriksaan (2017)

7. Tebing sungai tergerus akibat arus aliran sungai. Saran penanganan berupa pemasangan bronjong sepanjang $25 \mathrm{~m}$ di kedua sisi pada bagian

Tabel 10. Nilai Kondisi Daerah Aliran Sungai

\begin{tabular}{|c|c|c|c|c|c|c|c|c|}
\hline No. & $\begin{array}{c}\text { Tipe } \\
\text { Struktur }\end{array}$ & $S$ & $\mathrm{R}$ & $\mathrm{K}$ & $\mathrm{F}$ & $\mathrm{P}$ & NK & $\begin{array}{c}\text { Tingkat } \\
\text { Kerusakan }\end{array}$ \\
\hline 1. & DAS & 1 & 0 & 1 & 0 & 0 & 2 & \\
\hline & Nilai Ko & & & & & & 2 & $\begin{array}{l}\text { Rusak } \\
\text { Ringan }\end{array}$ \\
\hline
\end{tabular}

Sumber: Hasil Pemeriksaan (2017) 


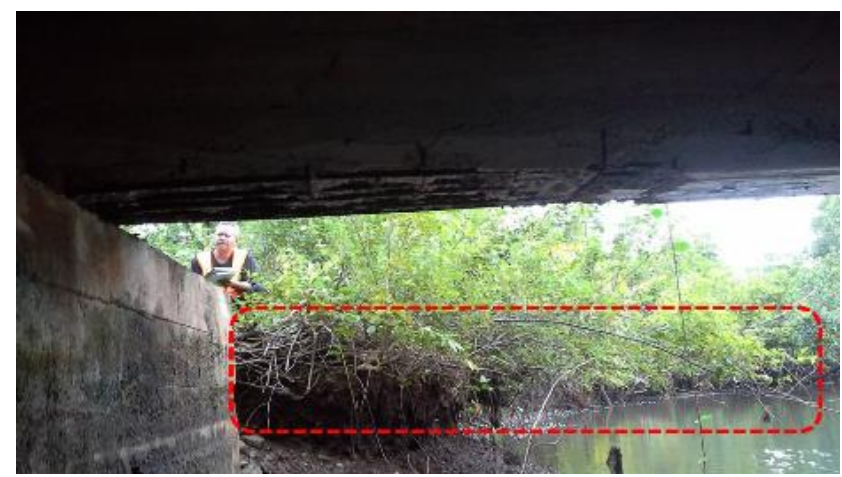

Gambar 10. Sungai yang tergerus

Sumber: Hasil Pemeriksaan (2017)

Tabel 11. Nilai Kondisi Keseluruhan Jembatan

\begin{tabular}{cccc}
\hline No. & Tipe Struktur & NK & $\begin{array}{c}\text { Tingkat } \\
\text { Kerusakan }\end{array}$ \\
\hline 1. & Lapisan Atas & 2 & Rusak Ringan \\
2. & Bagian Atas & 4 & Rusak Kritis \\
3. & Bagan Bawah & 3 & Rusak \\
4. & DAS & 2 & Rusak Ringan \\
\hline
\end{tabular}

Nilai Kondisi (NK) $3 \quad$ Rusak

Sumber: Hasil Pemeriksaan (2017)

Berdasarkan hasil pemeriksaan visual pada elemen-elemen yang ada pada Jembatan Siliti didapatkan nilai kondisi keseruruhan jembatan yaitu dengan nilai kondisi (NK) 3. Nilai kondisi tersebut mengindikasikan bahwa jembatan memiliki tingkat kerusakan "Rusak" dimana kerusakan tersebut diperlukan perhatian khusus dengan kemungkinan kerusakan tersebut akan menjadi serius pada selang waktu 12 bulan mendatang.

Berdasarkan nilai kondisi tersebut dan Tabel 3, maka penyaringan kondisi jembatan memerlukan penanganan indikatif dengan rehabilitasi ataupun penggantian dengan jembatan baru.

\section{Prediksi Usia Sisa}

Berdasarkan perhitungan nilai kondisi, maka prediksi sisa umur jembatan dapat dihitung dengan persamaan berikut:

$\begin{array}{ll}\text { NK } & \text { : Nilai Kondisi } \\ \mathrm{Y} & : \text { Umur Jembatan } \\ \mathrm{N} & : \text { Umur Rencana } \\ \mathrm{a} & \text { : Koefisien }(4,66) \\ \mathrm{b} & \text { : Koefisien }(1,9051)\end{array}$

$$
\begin{aligned}
& N K=5-\left\{\frac{\left(100-\frac{Y}{N \%}\right)}{a}\right\}\left(\frac{1}{b}\right) \\
& 3=5-\left\{\frac{\left(100-\frac{Y}{N \%}\right)}{4,66}\right\}^{\left(\frac{1}{1,9051}\right)} \\
& 2=\left\{\frac{\left(100-\frac{Y}{50 \%}\right)}{4,66}\right\}^{0.525} \\
& 2 x 4,66^{0.525}=\left(100-\frac{Y}{50 \%}\right)^{0.525} \\
& 4,486=\left(100-\frac{Y}{50 \%}\right)^{0.525} \\
& 0.525 \\
& 4,486=\left(100-\frac{Y}{50 \%}\right)^{0.525} \\
& 17,449=\left(100-\frac{Y}{50 \%}\right) \\
& 100-17,449=\frac{Y}{50 \%} \\
& 82,551=\frac{Y}{50 \%}
\end{aligned}
$$

$Y=41,275$ Tahun $\cong 42$ Tahun

Prediksi umur jembatan normal dengan nilai kondisi sebesar 3 adalah 42 tahun. Maka dari itu prediksi sisa umur berdasarkan metode Bina Marga (2011) adalah $=50-42=8$ tahun.

\section{PENUTUP}

\section{Kesimpulan}

1. Pemeriksan visual dengan menggunakan metode BMS (Bridge Management System) yang dilakukan pada Jembatan Siliti didapatkan nilai kondisi jembatan 3 (Rusak) terutama pada bagian struktur yang menopang jembatan (Bagian Atas dan Bagian Bawah).

2. Penggunaan metode BMS (Bridge Management System) pada pemeriksaan jembatan eksisting dapat menentukan penanganan indikatif pada jembatan.

3. Rekomendasi penanganan pada struktur utama seperti pada gelagar dan abutment sangat diperlukan. Mempertimbangkan biaya dan kondisi jembatan saat ini, perbaikan jembatan 
dengan rehabilitasi ataupun penggantian jembatan yang baru sangat diperlukan.

4. Menurut analisis umur sisa, Jembatan Siliti dengan Nilai Kondisi 3 memiliki umur jembatan normal 42 tahun,dengan umur rencana jembatan selama 50 tahun, maka umur sisa dari jembatan ini tersisa 8 tahun lagi.

\section{DAFTAR PUSTAKA}

Direktorat Jenderal Bina Marga, Kementrian Pekerjaan Umum, (2010). Panduan Penanganan Preservasi Jembatan, Jakarta, Direktorat Bina Teknik ISBN 978-602-972293-2.

Direktorat Jenderal Bina Marga Departemen Pekerjaan Umum, (1993), Bridge Management System Panduan Pemeriksaan Jembatan, Badan Penerbit Departemen Pekerjaan Umum. Hariman, F., H, H. C. \& Triwiyono, A., (2007), Evaluasi Dan Program Pemeliharaan Jembatan Dengan Metode Bridge Management System (BMS) (Studi Kasus: Empat Jembatan Propinsi D.I. Yogyakarta), Civil Engineering Forum Teknik Sipil, 17(3), pp. 581-593-593.

Indianto, A., (2016), Studi Kasus Kerusakan Jembatan Dan Pengaruhnya Terhadap Sisa Umur Jembatan, Politeknologi, 15(1).

Kementrian Pekerjaan Umum, (2011), Pedoman Pemeriksaan Jembatan, Jakarta, Direktorat Jenderal Bina Marga, No.00501/P/BM/2011.

Kementrian Pekerjaan Umum, (2011), Penentuan Nilai Sisa Kapasitas Jembatan, Jakarta, Direktorat Jenderal Bina Marga, No.024/BM/2011

Rasidi, N. et al. (2017). Analisis Alternatif Perkuatan Jembatan Rangka Baja (Studi Kasus : Jembaran Rangka Baja Soekarno-Hatta Malang), Eureka : Jurnal Penelitian Mahasiswa Teknik Sipil dan Teknik Kimia, 1, pp. 1-10.

Sudradjat, H., Djakfar, L., \& Zaika, Y., (2015). Penentuan Prioritas Penanganan Jembatan Pada Jaringan Jalan Provinsi Jawa Timur (Wilayah UPT Surabaya: Kota Surabaya, Kabupaten Sidoarjo dan Kabupaten Gresik), Rekayasa Sipil, 9(3), pp. 219-228. 